\title{
The effect of recurrent episodes of clinical mastitis caused by gram-positive and gram-negative bacteria and other organisms on mortality and culling in Holstein dairy cows
}

\author{
J. A. Hertl, ${ }^{\star 1}$ Y. H. Schukken, † D. Bar,‡ G. J. Bennett,† R. N. González,† B. J. Rauch,† F. L. Welcome,† \\ L. W. Tauer,§ and Y. T. Gröhn* \\ *Section of Epidemiology, Department of Population Medicine and Diagnostic Sciences, College of Veterinary Medicine, Cornell University, \\ Ithaca, NY 14853 \\ †Quality Milk Production Services, Department of Population Medicine and Diagnostic Sciences, College of Veterinary Medicine, \\ Cornell University, Ithaca, NY 14853 \\ ¥SCR Engineers Ltd., Netanya 42504, Israel \\ $\S$ Charles H. Dyson School of Applied Economics and Management, College of Agriculture and Life Sciences, Cornell University, Ithaca, NY 14853
}

\begin{abstract}
The objective of this study was to estimate the effects of recurrent episodes of different types of clinical mastitis (CM) caused by gram-positive (Streptococcus spp., Staphylococcus aureus, Staphylococcus spp.) and gram-negative (Escherichia coli, Klebsiella, Citrobacter, Enterobacter, Pseudomonas) bacteria, and other organisms (Arcanobacterium pyogenes, Mycoplasma, Corynebacterium bovis, yeast, miscellaneous) on the probability of mortality and culling in Holstein dairy cows. Data from 30,233 lactations in cows of 7 dairy farms in New York State were analyzed. Cows were followed for the first 10 mo in lactation, or until death or culling occurred, or until the end of our study period. Generalized linear mixed models with a Poisson error distribution were used to study the effects of recurrent cases of the different types of $\mathrm{CM}$ and several other factors (herd, parity, month of lactation, current year and season, profitability, net replacement cost, other diseases) on cows' probability of death (model 1) or being culled (model 2). Primiparous and multiparous cows were modeled separately because they had different risks of mortality and culling and potentially different $\mathrm{CM}$ effects on mortality and culling. Approximately $30 \%$ of multiparous cows had at least one case of CM in lactation compared with $16.6 \%$ of primiparous cows. Multipara also had higher lactational incidence risks of second $(10.7 \%)$ and third $(4.4 \%)$ cases than primipara (3.7\% and $1.1 \%$, respectively). For primipara, CM increased the probability of death, with each successive case occurring in a month being increasingly lethal. In multipara, gram-negative CM increased the probability of death, especially when the gram-negative case was
\end{abstract}

Received November 11, 2010.

Accepted June 3, 2011.

${ }^{1}$ Corresponding author: jah12@cornell.edu the first or second $\mathrm{CM}$ case in lactation. Primiparous cows with CM were more likely to be culled after CM than if they did not have CM, particularly after a second or third case. In multipara, any type of CM increased the probability of being culled. Gram-negative CM cases were associated with the numerically highest risk of culling.

Key words: gram-positive, gram-negative, recurrent mastitis, culling

\section{INTRODUCTION}

Mastitis in cows may be caused by a variety of organisms. The severity of the infection and its consequences are due, at least in part, to the pathogenicity of the organism(s) involved and the effect of the host response. Being able to identify the responsible pathogen, or at least the particular group of organisms to which it belongs, is therefore helpful in making treatment and other management decisions.

One commonly used grouping is to classify organisms as gram-positive or gram-negative. Some on-farm culture systems can classify pathogens in these categories (Neeser et al., 2006). Clinical symptoms and systemic severity of clinical mastitis (CM) cases generally differ depending on whether the causative organism is grampositive or gram-negative and on host characteristics (Schukken et al., 2009). Because gram-positive and gram-negative organisms respond differently to registered mastitis antimicrobial agents, on-farm treatment protocols frequently use bacteriological information to decide on the treatment to be used (Waage et al., 1994; Neeser et al., 2006). Nevertheless, many gram-negative mastitis cases are mild and do not need treatment (Pyörälä et al., 1994). Culture-negative results present a problem; they cannot simply be ignored, as they may require treatment and may have an effect on milk yield and other outcomes (Morin and Constable, 1998). 
Recent work has shown that new PCR techniques can detect bacterial DNA not found by traditional bacterial culture (Koskinen et al., 2010).

A recent study found that $\mathrm{CM}$ due to gram-negative bacteria caused more severe milk loss in Holstein dairy cows than did CM due to gram-positive bacteria or other organisms (Schukken et al., 2009). Similarly, Milne et al. (2003) observed a larger association between milk loss in Holstein-Friesians and gram-negative CM compared with gram-positive CM.

In addition to its effect on milk yield, gram-negative $\mathrm{CM}$ is more detrimental to reproductive success than is gram-positive $\mathrm{CM}$; the effect is greatest when $\mathrm{CM}$ occurs close to the time of insemination (Hertl et al., 2010). Huszenicza et al. (2005) studied the effects of mastitis on ovarian cyclicity in Hungarian Holsteins. They reported that the length of the follicular phase was greater in cows with gram-negative mastitis than in cows with gram-positive mastitis if the infection occurred during this phase.

Our research group has previously reported on the effects of pathogen-specific CM on herd life (Gröhn et al., 2005), but at the time of that research, sufficient data were available to study only the first occurrence of CM in a lactation. The database has been expanded since then, and a more recent study reported on the effects of recurrent generic CM episodes on mortality and culling (Bar et al., 2008a). The size of the database, however, did not allow a distinction of different types (e.g., gram-positive, gram-negative) of CM. Given the above findings of the effects of recurrent gram-positive and gram-negative CM episodes on milk loss and reproduction, it would be reasonable to hypothesize that these different types of CM might also differ in their effect on mortality and culling in dairy cows. Expansion of the database to address these issues has therefore continued.

In a New Zealand study, Compton et al. (2007) reported that heifers infected with a major pathogen (including Enterococcus spp., Escherichia coli, Klebsiella spp., Staphylococcus aureus, and Streptococcus spp.) 0 to $5 \mathrm{~d}$ after calving were $60 \%$ more likely to be culled later in that lactation compared with heifers not infected with a major pathogen. Waage et al. (2000) found that among heifers treated for CM before calving or within 2 wk after calving, $10.9 \%$ were culled within 1 mo of the episode. Whist et al. (2009) reported a 1.7-fold increase in hazard ratio of culling for cows with Staph. aureus CM compared with culture-negative cows.

Episodes of CM are important factors in herd management. The type of CM may determine the course of treatment and the ultimate fate of an individual cow. The objective of this study was to estimate (within lactation) the effects of recurrent episodes due to gram- positive bacteria, gram-negative bacteria, and other organisms on the probability of mortality and culling.

\section{MATERIALS AND METHODS}

\section{Herd Descriptions}

The data were collected from 7 dairy farms in New York State over a period of 4 to 5 yr (2003/2004-2008). Five of the study farms are located in central New York, one in northern New York, and one in western New York. All are large, well-managed, high-producing Holstein herds. The 305-d rolling herd average milk production was $11,320 \mathrm{~kg} / \mathrm{cow}$ per year, and monthly mean SCC was 225,000 cells $/ \mathrm{mL}$. Cows were housed in freestalls in covered barns and were managed in groups according to lactation month, production, and reproductive status. They were fed a balanced TMR and milked 3 times daily. The number of lactations per farm included in the study ranged from 2,085 to 7,804 , resulting in a total of 30,233 lactations. Cows were followed for the first 10 mo of each lactation, or until death or culling occurred, or until the end of the study (March 2008). The 10-mo limit was imposed to avoid confounding between pregnancy status and culling decisions (Bar et al., 2008a); after 10 mo (length of a standard 305-d lactation), open cows are culled more readily.

\section{Case Definition}

All lactating cows in the 7 herds were eligible for inclusion in the study. Milkers detected most CM cases, which were characterized by a warm, swollen udder or changes in milk consistency. The remaining cases were identified by herdspersons examining cows that were signaled by the farm computer system because their milk electrical conductivity was elevated $(>115 \%$ of the average of the previous $10 \mathrm{~d}$ ) combined with a sudden concurrent milk loss $(<70 \%$ of the average of the previous $10 \mathrm{~d}$ ), indicating $\mathrm{CM}$ cases missed by the milkers. Sick cows received treatment in accordance with well-defined protocols that were similar in all 7 farms and throughout the study. Treatments for cows with gram-positive CM included antibiotics, antiinflammatory drugs, and fluid intravenously or per os. Treatments for cows with gram-negative CM included anti-inflammatory drugs and fluid intravenously or per os. Treatments for cows with other types of CM included antibiotics, antiinflammatory medication, and fluid intravenously or per os. Farm personnel collected milk samples from quarters with CM signs for microbiological culturing at the Quality Milk Production Services laboratories (Ithaca, NY). The bacteriological culture 
procedures used in the current study were described in detail by Gröhn et al. (2004).

If a second CM episode occurred in the same quarter 5 or fewer days after the first one (irrespective of the etiologic agent isolated) or occurred within $14 \mathrm{~d}$ with the same etiologic agent isolated from both episodes, it was considered to be the same case of mastitis. In the former situation, the cause of CM was coded as the first-occurring agent. Any episode occurring more than $14 \mathrm{~d}$ after the previous episode was considered a new CM case (Barkema et al., 1998).

The unit of observation was lactation within the cow. If a cow had multiple quarter cases at the same time (e.g., E. coli in the left rear quarter and Staphylococcus spp. in the right front quarter, or both pathogens occurring in the same quarter), she was considered to have both E. coli and Staphylococcus spp.; both of these were accounted for in the analysis, with the episode being classified as both gram-negative and gram-positive.

\section{Other Diseases}

The main interest in this study was CM caused by gram-positive and gram-negative bacteria, and other organisms. Five other common clinical conditions [milk fever, retained placenta, metritis, ketosis, and displaced abomasum (DA)] were also chosen for inclusion as potential confounders in the models; they may be associated with both CM and herd life. They were defined as follows (see Gröhn et al., 2004): (1) milk fever: a cow was unable to rise or had cool extremities and sluggish rumen motility near the time of calving, but was successfully treated with calcium; (2) retained placenta: retention of fetal membranes for at least $24 \mathrm{~h}$ after calving; (3) metritis: a cow was febrile and had a purulent or fetid vaginal discharge, or an enlarged uterus detected by veterinary palpation; (4) ketosis: presence of ketones in milk or urine; and (5) DA: an abomasum enlarged with fluid, gas, or both, and that was mechanically trapped in either the left or right side of the abdominal cavity. Written disease definitions were disseminated to participating dairy producers and veterinarians to ensure that disease definition and diagnostic criteria were consistent across study farms.

\section{Statistical Analysis}

The effects of recurrent cases of the 3 types of CM, and several control variables (herd, parity, current season and year, month of lactation, and other diseases), on the probability of mortality were estimated. These same effects as well as those of 2 economic variables (monthly profitability and monthly net replacement cost; see below for details) on the probability of be- ing culled were estimated. These models were based on previous research with generic CM (Bar et al., 2008a). The PROC GLIMMIX procedure of SAS (SAS Institute, 2006) was used for this purpose (generalized linear mixed model). The rate of an event (e.g., mortality or culling) occurring due to various factors was modeled as

$$
\begin{gathered}
\operatorname{Ln}(\mathbf{P})=\beta_{0}+\beta_{1} \mathrm{x}_{1}+\beta_{2} \mathrm{x}_{2}+\beta_{3} \mathrm{x}_{3} \\
+\ldots+\beta_{\mathrm{k}} \mathrm{x}_{\mathrm{k}}+\mathbf{Z} \boldsymbol{\gamma}+\mathrm{R} \varepsilon
\end{gathered}
$$

where $\mathrm{Ln}$ is a link function, here the natural log of the odds of a cow dying or being sold in a month (time step); $\mathbf{P}$ is the vector of observations (either death or culling in a given month); $\beta_{0}$ is the regression parameter for the intercept, and $\beta_{1}, \beta_{2}, \beta_{3}, \ldots, \beta_{\mathrm{k}}$ are the regression coefficients for the fixed effects $\mathrm{x}_{1}, \mathrm{x}_{2}, \mathrm{x}_{3}, \ldots$, $\mathrm{x}_{\mathrm{k}}$ (see below); $\gamma$ is an unknown vector of random-effect parameters with known design matrix $\mathbf{Z}$; and $R \varepsilon$ is a complex Poisson error term including within-cow correlation $(\mathrm{R})$ and a random residual term $(\varepsilon)$; these errors are assumed independent and identically randomly distributed from a Poisson distribution.

Fixed effects included parity $(1,2,3$, and 4 and higher), month of lactation (1-10), current season (winter, spring, summer, fall), current year (2003-2008), other diseases, monthly profitability, and monthly net replacement cost. Monthly profitability was defined as monthly milk price - monthly operating cost. Milk prices were obtained from the USDA (USDA-National Agricultural Statistics Service, 2009) for each month of observation in the data set (January 2003 to March 2008), and are the wholesale prices (\$/cwt.) received by New York farmers. Operating costs were obtained from the USDA (USDA-Economic Research Service, 2010) for each month of observation and are the monthly dairy costs of production per hundredweight of milk sold (for New York farmers); they include feed costs, veterinary services, bedding and litter, marketing, custom services, fuel, and repairs. Monthly net replacement cost was defined as monthly purchase price of replacement - monthly cull price of cow. Purchase prices of replacements [milk cow herd replacements (\$/head)] and cull prices (slaughter cows $\times 12$, where "slaughter cows" is measured in dollars per hundredweight and the average mature Holstein weighs 1,200 lbs) were obtained from the USDA (USDA-National Agricultural Statistics Service, 2009) for each month of observation.

Herd was modeled as a random effect because specific farms were not of interest, but rather farms in general with similar characteristics to the study herds (large, high-milk-producing, and with a low incidence of contagious mastitis). Also included was a random 
Table 1. Covariate coding scheme used in mortality analysis: data for 4 example cows with different types of clinical mastitis (CM; none, grampositive, gram-negative, other organisms)

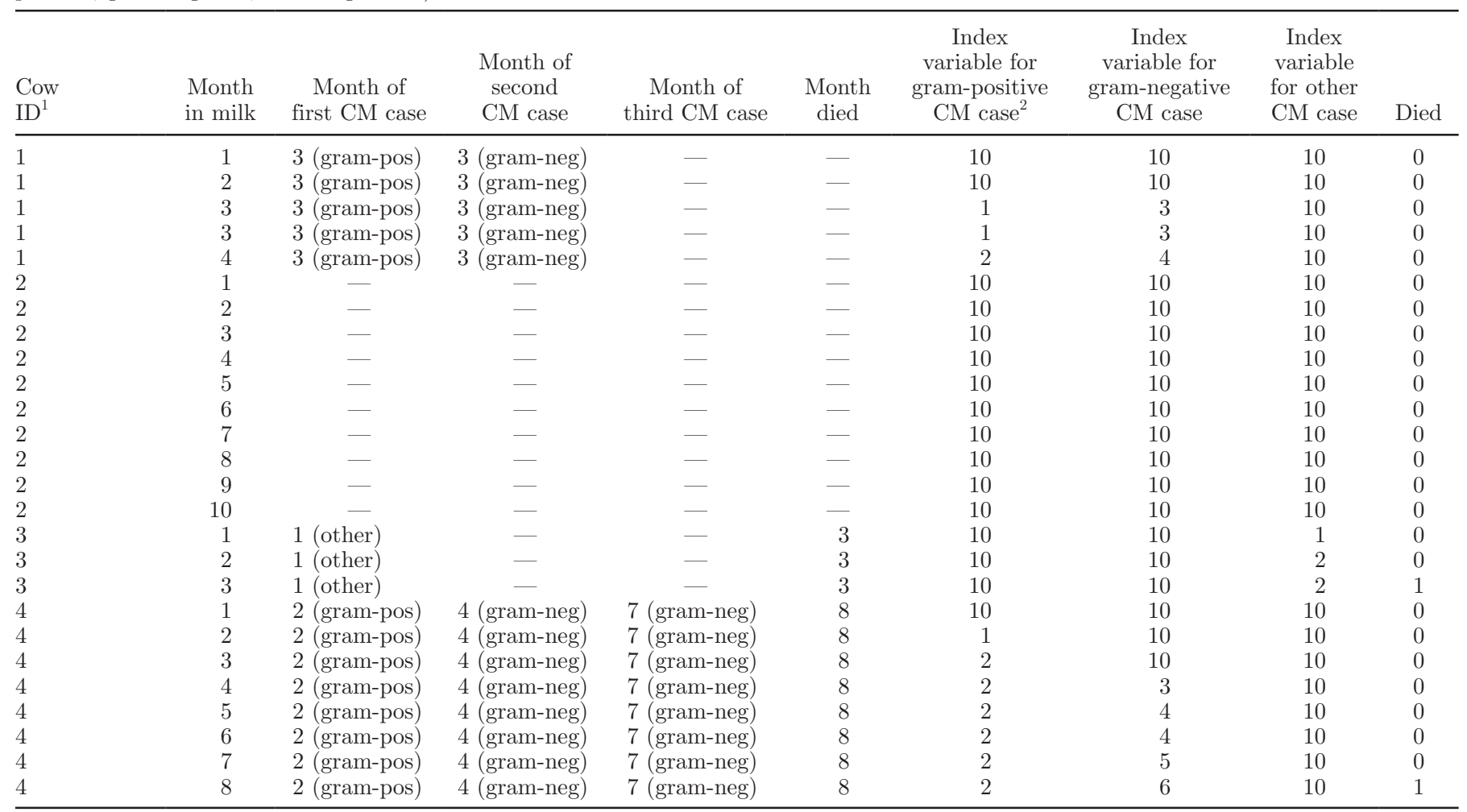

${ }^{1}$ If $2 \mathrm{CM}$ codes could apply to the same period (e.g., $2 \mathrm{CM}$ cases in the same month), the month was represented twice. Cow 1 is an example of this situation.

${ }^{2}$ Each CM index (for gram-positive CM, gram-negative CM, and other CM) had 7 levels: 1 = first CM case occurring in the current month of the lactation; 2 = first $\mathrm{CM}$ case occurring $\geq 1 \mathrm{mo}$ ago (in the same lactation); $3=$ second CM case occurring in the current month of the lactation; $4=$ second $\mathrm{CM}$ case occurring $\geq 1$ mo ago (in the same lactation); $5=$ third $\mathrm{CM}$ case occurring in the current month of the lactation; $6=$ third $\mathrm{CM}$ case occurring $\geq 1$ mo ago (in the same lactation); $10=$ free of $\mathrm{CM}$ in that month.

residual term, which accounts for the repeated effect of month within each lactation (SAS Institute, 2006).

For the mortality analysis, separate indices for each type of CM were created to account for the order of the CM case in lactation (first, second, third) and the month of occurrence of $\mathrm{CM}$, relative to the month under consideration (current month, or $\geq 1$ mo ago). These indices were treated as fixed effects. In the mortality analysis for each of the 3 types of CM (gram-positive, gram-negative, other organisms), the CM index had 7 levels (values of levels are in parentheses): first CM case occurring in the current month of the lactation (1); first $\mathrm{CM}$ case (in the current lactation) occurring $\geq 1 \mathrm{mo}$ ago (in the same lactation) (2); second CM case (in the current lactation) occurring in the current month (3); second $\mathrm{CM}$ case (in the current lactation) occurring $\geq 1$ mo ago (in the same lactation) (4); third CM case (in the current lactation) occurring in the current month of the lactation (5); third CM case (in the current lactation) occurring $\geq 1$ mo ago (in the same lactation) (6); and free of CM in the current month (10). Table 1 illustrates the coding scheme for the mortality analysis for 4 example cows.

A separate coding scheme was used in the culling analysis, because culling decisions may be made long after the precipitating event (e.g., a severe case of CM); the optimal time to sell one cow and acquire a replacement may depend on various exogenous factors, such as milk and beef prices, and price and availability of replacements. Table 2 illustrates the coding scheme for the culling analysis for 5 example cows. For each type of $\mathrm{CM}$, a separate CM index with 10 levels was created (values of levels are in parentheses): first CM case occurring in the current month of the lactation (1); first CM case occurring in the previous month (of the same lactation) (2); first CM case occurring 2 or more months ago (in the same lactation) (3); second CM case occurring in the current month of lactation (4); second CM case occurring in the previous month (of the same lactation) (5); second CM case occurring 2 or more months ago (in the same lactation) (6); third CM case occurring in the current month of lactation (7); 
Table 2. Covariate coding scheme used in culling analysis: data for 5 example cows with different types of clinical mastitis (CM; none, grampositive, gram-negative, other organisms)

\begin{tabular}{|c|c|c|c|c|c|c|c|c|c|}
\hline $\begin{array}{l}\text { Cow } \\
\text { ID }^{1}\end{array}$ & $\begin{array}{l}\text { Month } \\
\text { in milk }\end{array}$ & $\begin{array}{c}\text { Month of } \\
\text { first CM case }\end{array}$ & $\begin{array}{l}\text { Month of } \\
\text { second } \\
\text { CM case }\end{array}$ & $\begin{array}{c}\text { Month of } \\
\text { third CM case }\end{array}$ & $\begin{array}{l}\text { Month } \\
\text { sold }\end{array}$ & $\begin{array}{l}\text { Index variable } \\
\text { for gram- } \\
\text { positive } \\
\text { CM case }^{2}\end{array}$ & $\begin{array}{l}\text { Index variable } \\
\text { for gram- } \\
\text { negative } \\
\text { CM case }\end{array}$ & $\begin{array}{c}\text { Index } \\
\text { variable } \\
\text { for other } \\
\text { CM case }\end{array}$ & Sold \\
\hline 1 & 2 & - & - & - & 3 & 10 & 10 & 10 & 0 \\
\hline 1 & 3 & - & - & - & 3 & 10 & 10 & 10 & 1 \\
\hline 2 & 1 & 1 (other) & 2 (gram-neg) & - & 8 & 10 & 10 & 1 & 0 \\
\hline 2 & 5 & 1 (other) & 2 (gram-neg) & - & 8 & 10 & 6 & 3 & 0 \\
\hline 2 & 6 & 1 (other) & 2 (gram-neg) & - & 8 & 10 & 6 & 3 & 1 \\
\hline 3 & 1 & 1 (gram-pos, other) & 4 (gram-neg) & 7 (gram-pos) & 10 & 1 & 10 & 1 & 0 \\
\hline 3 & 2 & 1 (gram-pos, other) & 4 (gram-neg) & 7 (gram-pos) & 10 & 2 & 10 & 2 & 0 \\
\hline 3 & 3 & 1 (gram-pos, other) & 4 (gram-neg) & 7 (gram-pos) & 10 & 3 & 10 & 3 & 0 \\
\hline 3 & 4 & 1 (gram-pos, other) & 4 (gram-neg) & 7 (gram-pos) & 10 & 3 & 4 & 3 & 0 \\
\hline 3 & 10 & 1 (gram-pos, other) & 4 (gram-neg) & 7 (gram-pos) & 10 & 9 & 6 & 3 & 1 \\
\hline 4 & 1 & 2 (gram-neg) & - & - & - & 10 & 10 & 10 & 0 \\
\hline 4 & 2 & 2 (gram-neg) & - & - & - & 10 & 1 & 10 & 0 \\
\hline 4 & 3 & 2 (gram-neg) & - & - & - & 10 & 2 & 10 & 0 \\
\hline 4 & 4 & 2 (gram-neg) & - & - & - & 10 & 3 & 10 & 0 \\
\hline 4 & 5 & 2 (gram-neg) & - & - & - & 10 & 3 & 10 & 0 \\
\hline 4 & 6 & 2 (gram-neg) & - & - & - & 10 & 3 & 10 & 0 \\
\hline 5 & 1 & 3 (gram-pos) & 3 (gram-neg) & - & 4 & 10 & 10 & 10 & 0 \\
\hline 5 & 2 & 3 (gram-pos) & 3 (gram-neg) & - & 4 & 10 & 10 & 10 & 0 \\
\hline 5 & 3 & 3 (gram-pos) & 3 (gram-neg) & - & 4 & 1 & 4 & 10 & 0 \\
\hline 5 & 3 & 3 (gram-pos) & 3 (gram-neg) & - & 4 & 1 & 4 & 10 & 0 \\
\hline 5 & 4 & 3 (gram-pos) & 3 (gram-neg) & - & 4 & 2 & 5 & 10 & 0 \\
\hline 5 & 5 & 3 (gram-pos) & 3 (gram-neg) & - & 4 & 3 & 6 & 10 & 1 \\
\hline
\end{tabular}

${ }^{1}$ If 2 CM codes could apply to the same period (e.g., 2 CM cases in the same month), the month was represented twice. Cow 5 is an example of this situation.

${ }^{2}$ Each CM index (for gram-positive CM, gram-negative CM, and other CM) had 10 levels: 1 = first CM case occurring in the current month of the lactation; $2=$ first $\mathrm{CM}$ case occurring in the previous month (of the same lactation); 3 = first CM case occurring 2 or more months ago (in the same lactation); $4=$ second CM case occurring in the current month of lactation; $5=$ second CM case occurring in the previous month (of the same lactation); 6 = second $\mathrm{CM}$ case occurring 2 or more months ago (in the same lactation); $7=$ third CM case occurring in the current month of lactation; $8=$ third CM case occurring in the previous month (of the same lactation); $9=$ third CM case occurring 2 or more months ago (in the same lactation); $10=$ free of $\mathrm{CM}$ until that month.

third CM case occurring in the previous month (of the same lactation) (8); third CM case occurring 2 or more months ago (in the same lactation) (9); and free of CM until that month (10).

Primiparous cows (cows in their first lactation) and multiparous cows (cows in their second or higher lactation) were modeled separately because they had different risks of mortality and culling and potentially different CM effects. Only the first 10 mo of the lactation were modeled because pregnancy status could confound culling decisions after this time (Bar et al., 2008a): most cows capable of conceiving will have done so by this time; open cows are preferentially culled (Gröhn et al., 1998). For primipara, results for recurrent cases of generic CM only are reported because the models for recurrent cases of different types of $\mathrm{CM}$ did not consistently achieve convergence, possibly because there were too few cases to split into categories of gram-positive, gram-negative, and other. In summary, 4 models were fitted: (1a) effects of risk factors (month of lactation, recurrent cases of generic CM, other diseases, season, year) on mortality in primipara; (1b) effects of risk factors (parity, month of lactation, recurrent cases of different types of CM, other diseases, season, year) on mortality in multipara; (2a) effects of risk factors (month of lactation, recurrent cases of generic CM, other diseases, season, year, economic variables) on culling in primipara; and (2b) effects of risk factors (parity, month of lactation, recurrent cases of different types of CM, other diseases, season, year, economic 
variables) on culling in multipara. For all models, herd was included as a random effect. Statistical significance was defined at $P<0.05$.

\section{RESULTS}

\section{Descriptive Findings}

The proportion of cattle that died or were sold in the first 10 mo of lactation varied with study farm (range: 2.5 to $8.1 \%$ died; 11.2 to $19.1 \%$ culled). Almost all cows culled because of infertility or low milk yield were culled after 10 mo of lactation. At the end of this study, the farms had culled approximately one-third of all cows each year. Disease incidences also varied among the farms. Regarding CM, 4 of the farms had more initial cases than expected, whereas 3 had fewer. Recurrence of CM followed the same trend, with the same 4 farms having more second and third occurrences of $\mathrm{CM}$ and the same 3 farms having fewer than expected (results not shown).

Table 3 shows the number of cows having a first, second, or third case of $\mathrm{CM}$, and the number dying or being culled, by parity group, in the first 10 mo of lactation. Also shown is the median DIM of each event. A larger proportion of multipara $(29.9 \% ; 5,851$ cases in 19,578 lactations) than primipara $(16.6 \% ; 1,771$ cases in 10,655 lactations) had at least one case of CM. The same was true for second (10.7 vs. $3.7 \%$ ) and third cases (4.4 vs. $1.1 \%)$. The median DIM of each case was later for primipara than for multipara. A higher proportion of multipara than primipara died (8.7 vs. $4.0 \%$ ) or were culled (25.0 vs. $10.8 \%$ ). Among cows that died, the median day of death occurred much earlier in lactation than the median day of culling, regardless of parity group.

Figure 1 shows the risk of death by month of lactation for primiparous and multiparous cows with and without $\mathrm{CM}$ in the same month. The risks were calculated as follows: [number of cows that died (with CM) in a particular month/total number of cows (with CM in that month) at risk that month] and [number of cows that died (without CM) in a particular month/ total number of cows (without $\mathrm{CM}$ in that month) at risk that month]. Primipara with CM in mo 1 of lactation were more likely $(P<0.0001)$ to die in that month compared with primipara without $\mathrm{CM}$ in mo 1 . Primipara with $\mathrm{CM}$ in mo $6(P=0.0017)$ and $7(P<$ $0.0001)$ were also more likely to die in those months than were primipara without $\mathrm{CM}$ at that time. In all months, multipara with CM in a particular month were more likely $(P<0.001)$ to die than were multipara without CM.

Figure 2 shows the risk of culling by month of lactation for primiparous and multiparous cows with and without CM in the same month. The risks were calculated in the same manner as for risks of death in Figure 1. Except for mo 2, primipara with $\mathrm{CM}$ were more likely to be sold in the same month than were primipara without $\mathrm{CM}[P<0.0001$ for all months except mo $9(P=0.0024)]$. Multipara with $\mathrm{CM}$ in a particular month were more likely to be culled in the same month than multipara without CM in that month $(P<0.0001)$.

Of the 395 second-CM cases in primipara (Table 3 ), $123(31.1 \%)$ were caused by the same pathogen as was isolated in the first case. Of the 121 third-CM cases in primipara, $27(22.3 \%)$ included the same pathogen as was isolated in the first case, and $43(35.5 \%)$ included the same pathogen as was isolated in the second case.

Of the 2,093 second-CM cases in multipara (Table $3), 726(34.7 \%)$ showed the same pathogen as was isolated in the first case. Of the 854 third-CM cases in multipara, 239 (28.0\%) showed the same pathogen as was isolated in the first case, and $297(34.8 \%)$ included the same pathogen as was isolated in the second case.

Table 4 shows the distributions of CM pathogens isolated in this study, by type and parity group. Multipara had many more cases, even accounting for their higher cow numbers; that is, $65 \%$ of the cows were multiparous, but between 75 and $91 \%$ of most specific pathogens, especially gram-positive and gram-negative bacteria, were

Table 3. Number of cows, and median DIM of occurrence, having a first, second, or third case of clinical mastitis (CM), dying, or being culled in the first 10 mo of lactation, by parity group, in 7 New York State Holstein herds

\begin{tabular}{lrcrcr}
\hline & \multicolumn{2}{c}{$\begin{array}{c}\text { First lactations } \\
(\mathrm{n}=10,655)\end{array}$} & & \multicolumn{2}{c}{$\begin{array}{c}\text { Second and higher lactations } \\
(\mathrm{n}=19,578)\end{array}$} \\
\cline { 2 - 3 } \cline { 5 - 6 } Item & No. & Median DIM & & No. & Median DIM \\
\hline First CM case & 1,771 & 129 & & 5,851 & 101 \\
Second CM case & 395 & 204 & & 2,093 & 155 \\
Third CM case & 121 & 252 & & 854 & 193 \\
Mortality & 424 & 69 & & 1,698 & 66 \\
Culling & 1,155 & 241 & 4,899 & 199 \\
\hline
\end{tabular}




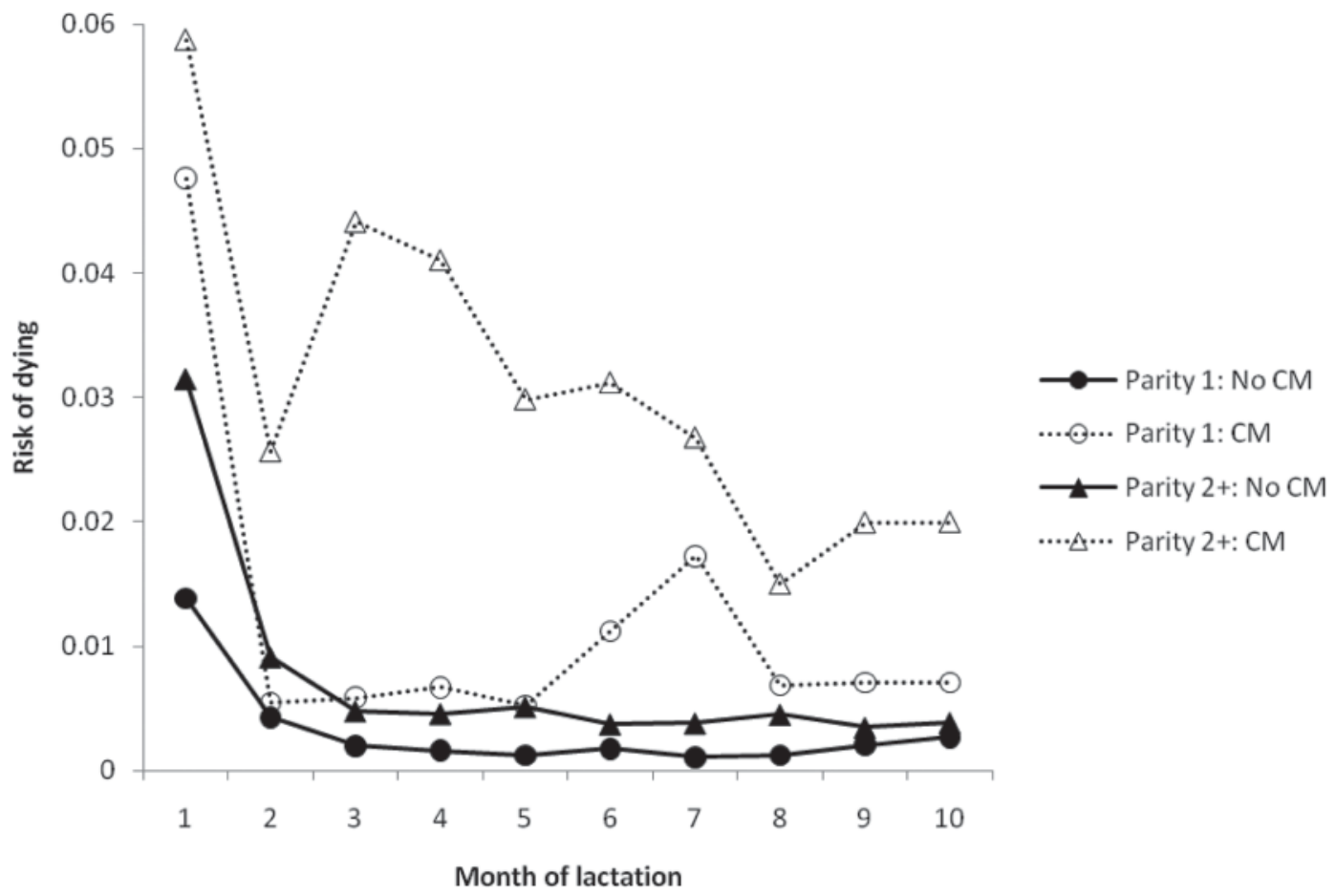

Figure 1. Risk of death, by parity group and absence or presence of clinical mastitis (CM) in the same month, in the first 10 mo of lactation, in 7 New York State Holstein herds.

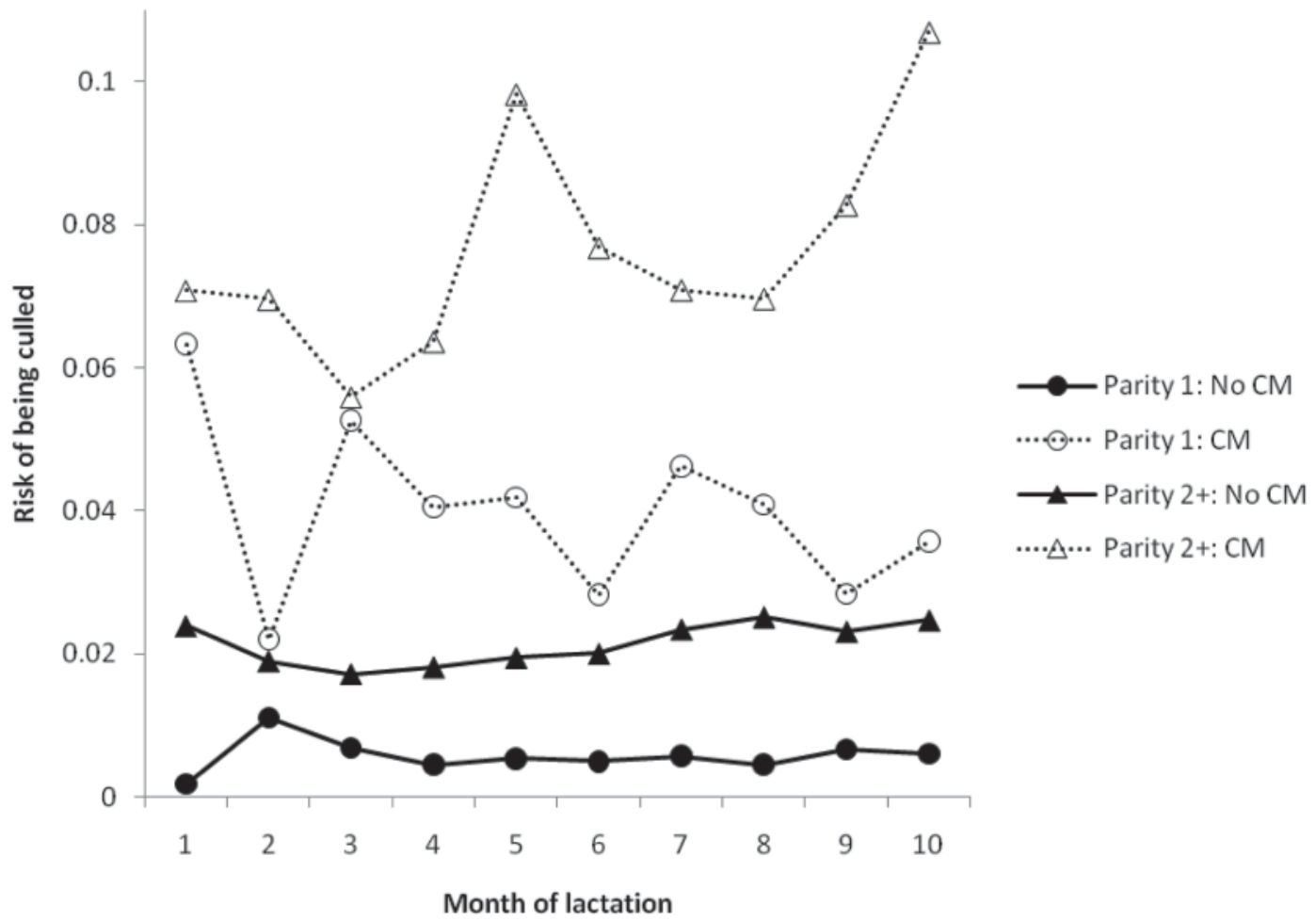

Figure 2. Risk of culling (being sold), by parity group and absence or presence of clinical mastitis (CM) in the same month, in the first 10 mo of lactation, in 7 New York State Holstein herds. 
isolated in multipara. In primipara, more gram-positive organisms $(\mathrm{n}=822)$ than gram-negative organisms ( $\mathrm{n}$ $=713$ ) were identified. The most commonly isolated pathogens in primipara were E. coli and Streptococcus spp. In contrast, in multipara, gram-negative organisms ( $\mathrm{n}=3,362)$ outnumbered gram-positive organisms $(\mathrm{n}=$ 2,818). As in primipara, E. coli and Streptococcus spp. were most commonly isolated in multipara.

\section{Effects of CM Cases on Mortality}

Primiparous Cows. For primipara, the probability of mortality was highest in the first month of lactation $[\exp (-6.11+1.64)=0.0114 ;$ model $1 \mathrm{a}$, Table 5$]$. The current season and year had no effect on probability of mortality. Mortality decreased after the first month of lactation and increased again at the end of lactation. Clinical mastitis cases occurring in the current month of lactation resulted in a higher $(P<0.001)$ risk of mortality (i.e., death occurred in the same month as $\mathrm{CM}$ ); cases occurring one or more months previously (in the same lactation) had no effect on mortality. Each successive case in the current month had a greater effect on risk of mortality: a cow with a first CM case was $\exp (1.37)=3.9$ times more likely to die in the same month than was a cow without CM; a cow with a second or third case was $\exp (2.11)=8.2$ times or $\exp (2.84)=$ 17.1 times more likely to die in the same month than a cow without CM, respectively. Retained placenta and DA were also risk factors for mortality in primipara. The probability of death can be calculated for an individual cow with any combination of characteristics, based on the relevant parameter estimates in Table 5 . For example, the risk of death for a cow in the second month of lactation having her first $\mathrm{CM}$ case and who also had retained placenta is $\exp (-6.11+0.51+1.37$ $+0.81)=0.0327$. If this cow had, instead, remained healthy, her risk of death would be $\exp (-6.11+0.51)$ $=0.0037$. For this final model, the $-2 \log$ pseudo-likelihood was 801,683.7 and the generalized $\chi^{2} /$ df was 1.03 , indicating that little residual variability existed in the marginal distribution of the data (SAS Institute, 2006). The herd covariance parameter estimate was 0.12 , with a standard error of 0.08 , indicating that the variance component due to farm was small and farms, therefore, did not vary importantly in baseline risk of mortality.

Multiparous Cows. As with primipara, in multipara, the highest risk of death occurred in mo 1 of lactation $[\exp (-5.17+1.77)=0.0334$; model $1 \mathrm{~b}$; Table $6]$, with a gradual decrease over time. Multiparous cows were more likely to die in spring (risk $=0.0069 ; P=$ 0.0254 ) and summer (risk $=0.0073 ; P=0.0021$ ) than in fall (risk $=0.0062$ ) or winter (risk $=0.0057)$. Cows were less likely to die in 2005 (risk $=0.0046 ; P=0.0085$ )
Table 4. Distribution of pathogens causing clinical mastitis (CM) in 7 New York State dairy herds, in primiparous and multiparous lactations ${ }^{1}$

\begin{tabular}{|c|c|}
\hline Lactation/group & No. \\
\hline \multicolumn{2}{|l|}{ First lactation } \\
\hline \multicolumn{2}{|l|}{ Gram-positive } \\
\hline Streptococcus spp. & 499 \\
\hline Staphylococcus aureus & 162 \\
\hline Staphylococcus spp. & 161 \\
\hline \multicolumn{2}{|l|}{ Gram-negative } \\
\hline Escherichia coli & 538 \\
\hline Klebsiella spp. & 154 \\
\hline Citrobacter & 10 \\
\hline Enterobacter & 11 \\
\hline \multicolumn{2}{|l|}{ Other } \\
\hline Arcanobacterium pyogenes & 70 \\
\hline Mycoplasma & 65 \\
\hline Corynebacterium bovis & 17 \\
\hline Yeast & 62 \\
\hline Miscellaneous & 255 \\
\hline Contamination & 52 \\
\hline Unknown $^{2}$ & 147 \\
\hline No growth ${ }^{3}$ & 441 \\
\hline \multicolumn{2}{|l|}{ Second and higher lactations } \\
\hline \multicolumn{2}{|l|}{ Gram-positive } \\
\hline Streptococcus spp. & 1,851 \\
\hline Staphylococcus aureus & 484 \\
\hline Staphylococcus spp. & 483 \\
\hline \multicolumn{2}{|l|}{ Gram-negative } \\
\hline Escherichia coli & 2,071 \\
\hline Klebsiella spp. & 1,128 \\
\hline Citrobacter & 97 \\
\hline Enterobacter & 66 \\
\hline Pseudomonas & 6 \\
\hline \multicolumn{2}{|l|}{ Other } \\
\hline Arcanobacterium pyogenes & 222 \\
\hline Mycoplasma & 56 \\
\hline Corynebacterium bovis & 26 \\
\hline Yeast & 165 \\
\hline Miscellaneous & 973 \\
\hline Contamination $^{4}$ & 176 \\
\hline Unknown $^{4}$ & 423 \\
\hline No growth $^{4}$ & 1,886 \\
\hline
\end{tabular}

${ }^{1}$ Total number of CM cases (comprising first, second, and third occurrences) in which the pathogen was identified. A cow may have a mixture of organisms in any one episode. For purposes of classifying an episode as gram-positive, gram-negative, or other, if more than one organism was present in an isolate, both were accounted for. For example, for an isolate containing both E. coli and Staphylococcus spp., the cow was considered to have both gram-negative and gram-positive infections.

${ }^{2}$ The etiologic agent was not identified in the cultured sample.

${ }^{3}$ No bacterial growth (i.e., no bacterial growth above the level of detection of our microbiological procedures) was observed in the cultured sample.

${ }^{4}$ Not included in the analysis.

than in 2006 (risk $=0.0057)$. Neither gram-positive CM nor CM caused by other organisms had an effect on mortality in the first 10 mo of lactation. Gram-negative CM, however, increased the risk of mortality: a cow with a first case was $\exp (0.84)=2.3$ times more likely to die in the same month than was a cow without CM, and a cow whose second case was caused by a gramnegative bacterium was $\exp (0.81)=2.2$ times more 
Table 5. Effects of the first 3 clinical mastitis (CM) cases and other factors on mortality in primiparous cows (10,655 lactations) in 7 New York State dairy farms over the first 10 mo of lactation ${ }^{1}$

\begin{tabular}{lr}
\hline Parameter & Estimate (SE) \\
\hline Intercept & $-6.11(0.30)^{* * *}$ \\
Spring & $0.02(0.18)$ \\
Summer & $0.25(0.17)$ \\
Autumn & $-0.02(0.17)$ \\
Winter (baseline) & 0.00 \\
Month 1 of lactation & $1.64(0.25)^{* * *}$ \\
Month 2 of lactation & $0.51(0.27)$ \\
Month 3 of lactation & $-0.24(0.32)$ \\
Month 4 of lactation & $-0.42(0.34)$ \\
Month 5 of lactation & $-0.61(0.36)$ \\
Month 6 of lactation & $-0.26(0.33)$ \\
Month 7 of lactation & $-0.49(0.35)$ \\
Month 8 of lactation & $-0.70(0.38)$ \\
Month 9 of lactation & $-0.18(0.33)$ \\
Month 10 of lactation (baseline) & 0.00 \\
First CM case occurring in current month of lactation ${ }^{2}$ & $1.37(0.19)^{* * *}$ \\
First CM case occurring $\geq 1$ mo ago & $0.43(0.27)$ \\
Second CM case occurring in current month of lactation & $2.11(0.44)^{* * *}$ \\
Second CM case occurring $\geq 1$ mo ago & $0.58(0.70)$ \\
Third CM case occurring in current month of lactation & $2.84(0.68)^{* * *}$ \\
Third CM case occurring $\geq 1$ mo ago & $1.17(0.95)$ \\
No CM in current month (baseline) & 0.0 \\
Retained placenta (yes vs. no) & \\
Displaced abomasum (yes vs. no) & $0.81(0.22)^{* * *}$ \\
${ }^{1}$ Estimates were obtained from a generalized mixed model with a Poisson distribution and random herd effect; \\
year was also included but estimates are not shown. & $1.24(0.19)^{* * *}$ \\
${ }^{2}$ The rate ratio is calculated as exp(1.37) = 3.94. & \\
$* * * P<0.001$. & \\
& \\
& \\
& \\
&
\end{tabular}

likely to die than was a cow without CM. Younger cows were less likely to die. Retained placenta, milk fever, and DA were also risk factors for mortality. As noted above, the probability of death can be calculated for individual cows. For example, a parity-2 cow in mo 5 of lactation who had her first case of CM (gram-negative) in that month has a risk of death of $\exp (-5.17-0.90+$ $0.47+0.84)=0.0086$. For this final model, the $-2 \log$ pseudo-likelihood was $1,190,342$, and the generalized $\chi^{2} / \mathrm{df}$ was 1.05 , indicating little residual variability. The herd covariance parameter estimate was 0.12 , with a standard error of 0.07 , indicating that the variance component due to farm was small and farms, therefore, did not vary importantly in baseline risk of mortality.

\section{Effects of CM Cases on Culling}

Primiparous Cows. Primipara were most likely to be culled in mo 1 of lactation (risk $=0.0198$; model 2a; Table 7). Current season had no effect on culling. Primipara were more likely to be culled in 2003 (risk $=0.0192 ; P=0.0035)$ than in 2006 (risk $=0.0087$ ). Neither of the economic variables included (monthly net replacement cost and monthly profit) had an effect on culling in primipara. All CM cases, whether the first, second, or third in the lactation, increased the risk of culling. The effect persisted even when CM occurred $\geq 2$ mo earlier in the lactation. Displaced abomasum also increased the risk of culling, whereas metritis was actually protective against culling. The risk of culling for an individual cow can be calculated in the same manner as the risk of death. For example, the risk of culling for a cow in mo 7 of lactation who had her first case of $\mathrm{CM}$ in the previous month is $\exp (-4.74+0.01$ $+1.81)=0.0539$. If this cow had not had $\mathrm{CM}$ at that time, her risk of culling would be lower $[\exp (-4.74+$ $0.01)=0.0088]$. For this final model, the $-2 \log$ pseudolikelihood was $698,682.9$, and the generalized $\chi^{2} / \mathrm{df}$ was 0.92 , indicating little residual variability. The herd covariance parameter estimate was 0.10 , with a standard error of 0.06 , indicating that the variance component due to farm was small and farms, therefore, did not vary importantly in baseline risk of culling.

Multiparous Cows. Older cows (parity 4 and higher) were more likely to be culled (risk $=0.0584$ ) than were parity-2 (risk $=0.0215)$ or parity-3 (risk $=$ 
Table 6. Effects of the first 3 clinical mastitis (CM) cases (due to gram-positive bacteria, gram-negative bacteria, or other organisms) and other factors on mortality in multiparous cows $\left(19,575\right.$ lactations $\left.^{1}\right)$ in 7 New York State dairy farms over the first 10 mo of lactation ${ }^{2}$

\begin{tabular}{|c|c|}
\hline Parameter & Estimate (SE) \\
\hline Intercept & $-5.17(0.22)^{* * *}$ \\
\hline Parity 2 & $-0.90(0.07)^{* * *}$ \\
\hline Parity 3 & $-0.41(0.07)^{* * *}$ \\
\hline Parity 4+ (baseline) & 0.0 \\
\hline Spring & $0.19(0.09)^{*}$ \\
\hline Summer & $0.25(0.08)^{* *}$ \\
\hline Autumn & $0.09(0.08)$ \\
\hline Winter (baseline) & 0.00 \\
\hline Month 1 of lactation & $1.77(0.16)^{* * *}$ \\
\hline Month 2 of lactation & $0.81(0.17)^{* * *}$ \\
\hline Month 3 of lactation & $0.57(0.18)^{* *}$ \\
\hline Month 4 of lactation & $0.46(0.18)^{*}$ \\
\hline Month 5 of lactation & $0.45(0.18)^{*}$ \\
\hline Month 6 of lactation & $0.18(0.19)$ \\
\hline Month 7 of lactation & $0.15(0.20)$ \\
\hline Month 8 of lactation & $0.14(0.20)$ \\
\hline Month 9 of lactation & $-0.07(0.21)$ \\
\hline Month 10 of lactation (baseline) & 0.00 \\
\hline First CM case (gram-positive) occurring in current month of lactation ${ }^{3}$ & $-0.21(0.23)$ \\
\hline First CM case (gram-positive) occurring $\geq 1$ mo ago & $-0.09(0.19)$ \\
\hline Second CM case (gram-positive) occurring in current month of lactation & $0.30(0.44)$ \\
\hline Second CM case (gram-positive) occurring $\geq 1$ mo ago & $0.34(0.35)$ \\
\hline Third CM case (gram-positive) occurring in current month of lactation & $0.52(0.72)$ \\
\hline Third CM case (gram-positive) occurring $\geq 1$ mo ago & $-0.88(1.01)$ \\
\hline No gram-positive CM in current month (baseline) & 0.0 \\
\hline First CM case (gram-negative) occurring in current month of lactation & $0.84(0.13)^{* * *}$ \\
\hline First $C M$ case (gram-negative) occurring $\geq 1$ mo ago & $-0.04(0.17)$ \\
\hline Second CM case (gram-negative) occurring in current month of lactation & $0.81(0.32)^{*}$ \\
\hline Second CM case (gram-negative) occurring $\geq 1$ mo ago & $0.35(0.30)$ \\
\hline Third CM case (gram-negative) occurring in current month of lactation & $0.10(0.75)$ \\
\hline Third CM case (gram-negative) occurring $\geq 1$ mo ago & $-0.75(0.76)$ \\
\hline No gram-negative CM in current month (baseline) & 0.00 \\
\hline First CM case (other) occurring in current month of lactation & $0.30(0.23)$ \\
\hline First CM case (other) occurring $\geq 1 \mathrm{mo}$ ago & $-0.10(0.26)$ \\
\hline Second CM case (other) occurring in current month of lactation & $-0.00(0.52)$ \\
\hline Second CM case (other) occurring $\geq 1$ mo ago & $-0.17(0.52)$ \\
\hline Third CM case (other) occurring in current month of lactation & $-0.09(1.04)$ \\
\hline Third CM case (other) occurring $\geq 1$ mo ago & $0.50(0.76)$ \\
\hline No "other" organism CM in current month (baseline) & 0.00 \\
\hline Retained placenta (yes vs. no) & $0.52(0.10)^{* * *}$ \\
\hline Milk fever (yes vs. no) & $1.40(0.12)^{* * *}$ \\
\hline Displaced abomasum (yes vs. no) & $0.57(0.10)^{* * *}$ \\
\hline
\end{tabular}

$0.0367)$ cows $(P<0.0001$; model 2b; Table 8). Cows were less likely to be culled in spring (risk $=0.0470$ ) than in winter (risk $=0.0584 ; P<0.0001$ ). Cows were more likely to be culled in 2007 (risk $=0.0661 ; P=$ 0.0225 ) and less likely to be culled in 2008 (risk = $0.0396 ; P=0.0001$ ) than in 2006 (risk $=0.0584$ ). Cows were less likely to be voluntarily culled in mid lactation than at the beginning or end. The higher the monthly profit was, the more likely a cow was to be culled. A $\$ 1$ increase in monthly profit resulted in an increase in risk of culling from $\exp (-2.84)=0.0584$ to $\exp (-2.84$ $+0.03 \times 1.00)=0.0602$. The greater the net replacement cost was, the lower was the probability of culling. A $\$ 100$ increase in net replacement cost resulted in a 
Table 7. Effects of the first 3 clinical mastitis (CM) cases and other factors on culling in primiparous cows $\left(10,655\right.$ lactations) in 7 New York State dairy farms over the first 10 mo of lactation ${ }^{1}$

\begin{tabular}{lc}
\hline Parameter & Estimate (SE) \\
\hline Intercept & $-4.74(0.52)^{* * *}$ \\
Spring & $-0.08(0.10)$ \\
Summer & $-0.10(0.12)$ \\
Autumn & $-0.19(0.13)$ \\
Winter (baseline) & 0.00 \\
Month 1 of lactation & $0.82(0.16)^{* * *}$ \\
Month 2 of lactation & $0.56(0.16)^{* * *}$ \\
Month 3 of lactation & $0.20(0.17)$ \\
Month 4 of lactation & $-0.20(0.19)$ \\
Month 5 of lactation & $-0.04(0.18)$ \\
Month 6 of lactation & $-0.18(0.19)$ \\
Month 7 of lactation & $0.01(0.18)$ \\
Month 8 of lactation & $-0.23(0.19)$ \\
Month 9 of lactation & $0.06(0.18)$ \\
Month 10 of lactation (baseline) & 0.00 \\
First CM case occurring in current month of lactation ${ }^{2}$ & $1.89(0.12)^{* * *}$ \\
First CM case occurring in previous month & $1.81(0.15)^{* * *}$ \\
First CM case occurring $\geq 2$ mo ago & $0.70(0.16)^{* * *}$ \\
Second CM case occurring in current month of lactation & $2.31(0.24)^{* * *}$ \\
Second CM case occurring in previous month & $2.77(0.25)^{* * *}$ \\
Second CM case occurring $\geq 2$ mo ago & $0.89(0.42)^{*}$ \\
Third CM case occurring in current month of lactation & $2.39(0.48)^{* * *}$ \\
Third CM case occurring in previous month & $2.84(0.43)^{* * *}$ \\
Third CM case occurring $\geq 2$ mo ago & $2.53(0.36)^{* * *}$ \\
No CM in current month (baseline) & 0.0 \\
Metritis (yes vs. no) & $-1.86(0.82)^{*}$ \\
Displaced abomasum (yes vs. no) & $0.56(0.16)^{* * *}$ \\
\hline Estimates wo & \\
& \\
&
\end{tabular}

${ }^{1}$ Estimates were obtained from a generalized mixed model with a Poisson distribution and random herd effect; year, monthly profitability, and monthly net replacement cost were also included but estimates are not shown.

${ }^{2}$ The rate ratio is calculated as $\exp (1.89)=6.62$.

$* P<0.05 ;{ }^{* * *} P<0.001$.

decrease in risk of culling from $\exp (-2.84)=0.0584$ to $\exp (-2.84-0.0004 \times 100)=0.0561$. All 3 types of CM (gram-positive, gram-negative, other organisms), regardless of case number or how long ago it had occurred, increased the risk of culling. For the first CM case in a lactation, gram-negative $\mathrm{CM}$ occurring in the previous or current month was associated with a higher $(P<0.05)$ risk of culling in multiparous cows than CM due to gram-positive or other organisms. In a second $\mathrm{CM}$ case, gram-positive $\mathrm{CM}$ in the current month was less likely $(P<0.05)$ to result in culling than $\mathrm{CM}$ due to gram-negative bacteria; $\mathrm{CM}$ due to other organisms occurring more than 1 mo previously was less likely $(P$ $<0.05)$ to result in culling than was CM due to grampositive or gram-negative bacteria. In a third case, CM caused by other organisms occurring more than 1 mo ago was less likely $(P<0.05)$ to result in culling than if the $\mathrm{CM}$ was due to gram-positive or gram-negative bacteria. Milk fever, ketosis, and DA increased the risk of culling, whereas retained placenta decreased it.

As seen above, the risk of culling can be calculated for individual cow characteristics. For example, the risk of culling for a parity-2 cow in mo 4 of lactation who had had gram-positive CM in mo 3 and then gram-negative $\mathrm{CM}$ in mo 4 is $\exp (-2.84-1.00-0.32+0.87+0.99)$ $=0.1003$. If this cow had not had a second CM case, her risk of culling would only be $\exp (-2.84-1.00-$ $0.32+0.87)=0.0373$. For this final model, the $-2 \log$ pseudo-likelihood was 979,028.7, and the generalized $\chi^{2} /$ df was 0.85 , indicating little residual variability. The herd covariance parameter estimate was 0.07 , with a standard error of 0.04 , indicating that the variance component due to farm was small and farms, therefore, did not vary importantly in baseline risk of culling.

\section{DISCUSSION}

Mastitis is a complex disease with many ramifications. Its effects on milk production (e.g., Seegers et al., 2003; Gröhn et al., 2004; Bar et al., 2007; Schukken et al., 2009) and reproduction (e.g., Santos et al., 2004; Perrin et al., 2007; Hertl et al., 2010) have been well studied. It is also responsible for death and culling of cattle (e.g., Neerhof et al., 2000; Seegers et al., 2003; 
Table 8. Effects of the first 3 clinical mastitis (CM) cases (due to gram-positive bacteria, gram-negative bacteria, or other organisms) and other factors on culling in multiparous cows $\left(19,575\right.$ lactations $\left.^{1}\right)$ in 7 New York State dairy farms over the first 10 mo of lactation ${ }^{2}$

\begin{tabular}{|c|c|}
\hline Parameter & Estimate (SE) \\
\hline $\begin{array}{l}\text { Intercept } \\
\text { Parity } 2 \\
\text { Parity } 3 \\
\text { Parity } 4+\text { (baseline) } \\
\text { Spring } \\
\text { Summer } \\
\text { Autumn } \\
\text { Winter (baseline) }\end{array}$ & $\begin{array}{l}-2.84(0.23)^{* * *} \\
-1.00(0.04)^{* * *} \\
-0.46(0.03)^{* * *} \\
0.0 \\
-0.22(0.05)^{* * *} \\
-0.05(0.05) \\
-0.09(0.06) \\
0.00\end{array}$ \\
\hline $\begin{array}{l}\text { Monthly profitability } \\
\text { Monthly net replacement cost } \\
\text { Month } 1 \text { of lactation } \\
\text { Month } 2 \text { of lactation } \\
\text { Month } 3 \text { of lactation } \\
\text { Month } 4 \text { of lactation } \\
\text { Month } 5 \text { of lactation } \\
\text { Month } 6 \text { of lactation } \\
\text { Month } 7 \text { of lactation } \\
\text { Month } 8 \text { of lactation } \\
\text { Month } 9 \text { of lactation } \\
\text { Month } 10 \text { of lactation (baseline) }\end{array}$ & $\begin{array}{l}0.03(0.01)^{* *} \\
-0.0004(0.0002)^{*} \\
-0.01(0.07) \\
-0.28(0.07)^{* * *} \\
-0.37(0.07)^{* * *} \\
-0.32(0.07)^{* * *} \\
-0.17(0.07)^{*} \\
-0.22(0.07)^{* *} \\
-0.10(0.07) \\
-0.04(0.07) \\
-0.09(0.07) \\
0.00\end{array}$ \\
\hline $\begin{array}{l}\text { First CM case (gram-positive) occurring in current month of lactation }{ }^{3} \\
\text { First CM case (gram-positive) occurring in previous month } \\
\text { First CM case (gram-positive) occurring } \geq 2 \text { mo ago } \\
\text { Second CM case (gram-positive) occurring in current month of lactation } \\
\text { Second CM case (gram-positive) occurring in previous month } \\
\text { Second CM case (gram-positive) occurring } \geq 2 \text { mo ago } \\
\text { Third CM case (gram-positive) occurring in current month of lactation } \\
\text { Third CM case (gram-positive) occurring in previous month } \\
\text { Third CM case (gram-positive) occurring } \geq 2 \text { mo ago } \\
\text { No gram-positive CM in current month (baseline) }\end{array}$ & $\begin{array}{l}0.52(0.10)^{* * *} \\
0.87(0.10)^{* * *} \\
0.19(0.08)^{*} \\
0.48(0.16)^{* *} \\
0.89(0.16)^{* * *} \\
0.65(0.12)^{* * *} \\
0.93(0.18)^{* * *} \\
0.67(0.25)^{* *} \\
0.91(0.18)^{* * *} \\
0.00\end{array}$ \\
\hline $\begin{array}{l}\text { First CM case (gram-negative) occurring in current month of lactation } \\
\text { First CM case (gram-negative) occurring in previous month } \\
\text { First CM case (gram-negative) occurring } \geq 2 \text { mo ago } \\
\text { Second CM case (gram-negative) occurring in current month of lactation } \\
\text { Second CM case (gram-negative) occurring in previous month } \\
\text { Second CM case (gram-negative) occurring } \geq 2 \text { mo ago } \\
\text { Third CM case (gram-negative) occurring in current month of lactation } \\
\text { Third CM case (gram-negative) occurring in previous month } \\
\text { Third CM case (gram-negative) occurring } \geq 2 \text { mo ago } \\
\text { No gram-negative CM in current month (baseline) }\end{array}$ & $\begin{array}{l}1.17(0.07)^{* * *} \\
1.21(0.08)^{* * *} \\
0.35(0.07)^{* * *} \\
0.99(0.13)^{* * *} \\
0.93(0.15)^{* * *} \\
0.59(0.12)^{* * *} \\
0.92(0.18)^{* * *} \\
1.08(0.20)^{* * *} \\
0.84(0.16)^{* * *} \\
0.00\end{array}$ \\
\hline $\begin{array}{l}\text { First CM case (other) occurring in current month of lactation } \\
\text { First CM case (other) occurring in previous month } \\
\text { First CM case (other) occurring } \geq 2 \text { mo ago } \\
\text { Second CM case (other) occurring in current month of lactation } \\
\text { Second CM case (other) occurring in previous month } \\
\text { Second CM case (other) occurring } \geq 2 \text { mo ago } \\
\text { Third CM case (other) occurring in current month of lactation } \\
\text { Third CM case (other) occurring in previous month } \\
\text { Third CM case (other) occurring } \geq 2 \text { mo ago } \\
\text { No "other" CM in current month (baseline) }\end{array}$ & $\begin{array}{l}0.63(0.12)^{* * *} \\
0.73(0.13)^{* * *} \\
0.22(0.10)^{*} \\
0.73(0.16)^{* * *} \\
0.70(0.20)^{* * *} \\
0.25(0.16) \\
0.82(0.21)^{* * *} \\
0.99(0.25)^{* * *} \\
0.19(0.25) \\
0.00\end{array}$ \\
\hline $\begin{array}{l}\text { Retained placenta (yes vs. no) } \\
\text { Milk fever (yes vs. no) } \\
\text { Ketosis (yes vs. no) } \\
\text { Displaced abomasum (yes vs. no) }\end{array}$ & $\begin{array}{r}-0.28(0.12)^{*} \\
0.54(0.15)^{* * *} \\
0.19(0.05)^{* * *} \\
0.33(0.06)^{* * *}\end{array}$ \\
\hline
\end{tabular}

${ }^{1}$ Three lactations not included due to convergence problems.

${ }^{2}$ Estimates were obtained from a generalized mixed model with a Poisson distribution and random herd effect; year was also included but estimates are not shown.

${ }^{3}$ The rate ratio is calculated as $\exp (0.52)=1.68$.

${ }^{*} P<0.05 ;{ }^{* *} P<0.01 ;{ }^{* * *} P<0.001$. 
Bar et al., 2008a). In this study, different aspects (e.g., case number, type, timing) of $\mathrm{CM}$ and their effects on mortality or culling of dairy cows were accounted for simultaneously. Economic factors related to milk price, operating costs, cow replacement prices, and carcass value were also accounted for in the culling models. These were associated with culling in multipara, but not in primipara. It appears that for older cows, economic considerations become a factor in whether or not to cull.

The effects of milk yield and reproduction were not included in the models. Although they are important factors in culling decisions, they act as intervening variables in the CM-culling association, and the indirect effect of CM through milk yield or reproduction was not of interest in the current study. Therefore, it would be inappropriate to include them (Kleinbaum et al., 1982; Gröhn et al., 2005).

Severity of CM cases was also not included. Although it is an important factor, comprehensive data on it were not available, because it was not recorded systematically. Our ultimate goal (beyond this study) is to develop a decision-making tool for the 3 categories of $\mathrm{CM}$ (gram-positive, gram-negative, other).

Additional farm, local, and regional factors, such as barn space limitations, labor shortages, milk quality bonus programs, and so on, may also play a role in culling decisions. These could be of interest in future research.

Any of several different organisms may cause a CM case. These different organisms differ in their pathogenicity and therefore show a difference in short-term and long-term consequences. In this study, 3 groups of pathogens (gram-positive, gram-negative, and other organisms) were considered.

In the current study, the monthly probability of mortality and culling was of interest. Generalized linear mixed models with a Poisson error distribution using monthly data are appropriate for estimating the risk of an event (e.g., mortality or culling; Hedeker et al., 2000; Bar et al., 2008a) and were used in this study. This model is appropriate for rare events and performs well in the type of data present in this study (Schukken et al., 2010). Poisson models allowed for simultaneous estimation of random effects at the cow and herd levels while providing valid estimates for the rate of culling for the fixed effects in the regression model. A time step of 1 mo was used because a related economic dynamic program was simultaneously developed to use these results, and this program uses a monthly time step (Bar et al., 2008b). Given the relative rarity of the events of interest and the short time step of 1 mo that was used in the models, rate and risk were considered as interchangeable throughout this paper. Models assum- ing a binomial distribution (not shown) were also fit, but these had a poorer fit than did the Poisson models, as judged by the $-2 \log$ pseudo-likelihood. Given the relatively low incidence of death and culling, this may be expected.

A distinction should be made between mortality (death) and culling. In this study, mortality was defined as on-farm mortality, where the cow dies or is euthanized on the farm, and is unable to be sold (e.g., due to certain diseases), thus having no market value. In culling, a cow is shipped off the farm for sale as a dairy animal elsewhere or for slaughter, thus generating income. Culling mostly involves a voluntary economic decision: a farmer can decide whether and when to sell a cow and replace her. The cull decision may depend on several factors, including milk yield, disease, reproductive status, parity, and stage of lactation, as well as milk and beef prices, and disease treatment costs (Bar et al., 2008b; Dechow and Goodling, 2008) or even sale for calf or embryo production elsewhere (Fetrow et al., 2006). For example, if a nonpregnant cow with average milk production suffers several episodes of CM in a lactation, each time resulting in severe milk loss, the farmer may decide to replace her with a healthy first-lactation animal. Many other farm, local, and regional factors, such as physical facility limitations, milk quality bonus programs, and supply-management milk quota marketing systems, may also influence culling decisions.

Primipara and multipara were modeled separately, as their risks of death and culling, as well as CM pathogen distribution, differ importantly (Dechow and Goodling, 2008; Sampimon et al., 2009). Due to sparse data for primipara when categorizing CM cases by causative agent group (gram-positive, gram-negative, other), it was not possible to estimate the effects of these groups on risk of death and culling. Therefore, CM without group identification was modeled as a risk factor in primipara.

Figures 1 and 2 show increases in death and culling risks, respectively, at different times of lactation. Cows are particularly at high risk of death in early lactation, whereas the likelihood of culling is more equal across lactation, with slightly higher rates at the beginning and end of lactation (the so-called bathtub effect). The higher rate of culling observed in later lactation likely also reflects the occurrence of subsequent (i.e., second and third cases) of CM. When the data were corrected for mastitis occurrence (Tables 7 and 8), however, an increased rate of culling was still observed toward the end of lactation.

In primipara, the highest risk of death occurred in mo 1 of lactation. Cows are under higher metabolic stress in early lactation and thus more vulnerable to various 
infections. In primipara, only CM cases occurring in the current month increased the risk of death; cases occurring further back in time had no effect (Table 5). Second and third cases in the same month were associated with even higher risks of death. These findings suggest a cumulative effect of $\mathrm{CM}$, with the additional cases taking an increasing toll on the cow's survival ability. A very similar cumulative effect was observed in milk production losses due to multiple cases of CM (Schukken et al., 2009). As was shown in the case of milk production loss, the observational data showed little evidence for protective effects of a previous episode of $\mathrm{CM}$ on the consequences due to the next case of CM.

In multiparous cows, gram-negative $\mathrm{CM}$ increased the risk of death; CM due to gram-positive or other organisms had no effect. In previous studies on milk yield (Schukken et al., 2009) and reproduction (Hertl et al., 2010), gram-negative CM was more detrimental than CM caused by gram-positive or other organisms. One of the mechanisms associated with severity of disease is the release of endotoxin from gram-negative bacteria, thereby increasing risk of death in affected cows. In addition, previous studies have shown that cows with gram-negative CM were more likely to show sepsis due to dislocation of bacteria (Wenz et al., 2001).

Primipara were most likely to be voluntarily culled in the first 2 mo of lactation (Table 7). All CM cases, regardless of the numerical order (first, second, third) or when in lactation they occurred, increased the subsequent risk of culling. Risks of culling increased with case number of CM. These findings suggest that farmers are not very tolerant of CM in primipara.

All 3 types of CM and all cases (whether first, second, third) increased a multiparous cow's risk of being voluntarily culled (Table 8). Gram-negative CM had the largest effect on the risk of culling. Although, in general, gram-negative CM is associated with more severe clinical symptoms than is gram-positive CM, cows with gram-negative CM are often higher producers (before $\mathrm{CM}$ ) compared with cows with gram-positive $\mathrm{CM}$ (before $\mathrm{CM}$ ), and both are higher producers before CM than are non-CM cows (Schukken et al., 2009). Therefore, we can hypothesize that a farmer is more likely to keep a gram-negative $\mathrm{CM}$ cow in the milking herd than a gram-positive CM cow initially; that is, cows remain in the herd long enough to acquire subsequent CM cases. Later, however, the opposite may be true, and it may become more worthwhile to replace the cow. Overall, the findings indicate that gram-negative CM is more unfavorable for the cow as judged by farmers than are other types of CM. This is likely due to severe systemic signs in the cow and with greater milk loss, as reported in other studies and discussed above (e. g.,
Bradley and Green, 2001; Milne et al., 2003; Schukken et al., 2009).

The current study was based on clinical cases of mastitis. Among the clinical cases of gram-negative bacterial mastitis, the data were in agreement with previous studies (Schukken et al., 2009; Hertl et al., 2010) that the consequences of gram-negative bacterial mastitis are more severe. Among samples exhibiting no growth (Table 4), however, there may be many gram-negative bacteria but, as a category, these no-growth samples had less severe consequences. Thus, gram-negative cases may be mild or severe; in the current study, they were more severe.

This study provides evidence that knowing the group of organisms causing CM (gram-positive, gram-negative, other organisms), rather than knowing only the observable signs of CM, appears to be predictive in the management of CM cows. For example, multiparous cows with gram-negative CM (in the first or second CM case) were much more likely to die than cows in which CM was caused by gram-positive or other organisms. In addition, cows with a case of gram-negative CM are more likely to be sold than are cows with any other type of CM. This precise information, although intuitively obvious, may assist dairy producers who experience a high proportion of gram-negative CM cases in their herd in general or during specific seasons. Culling and treatment decisions may be affected by having this quantitative information of death and culling risk (Roberson, 2003; Neeser et al., 2006).

\section{ACKNOWLEDGMENTS}

The USDA (CSREES) Award No. 2005-35204-15714 provided funding for this study. The authors thank owners and personnel from the 7 dairies, and the personnel of the Ithaca, Canton, and Geneseo Regional Laboratories of Quality Milk Production Services for their valuable cooperation.

\section{REFERENCES}

Bar, D., Y. T. Gröhn, G. Bennett, R. N. González, J. A. Hertl, H. Schulte, L. W. Tauer, F. L. Welcome, and Y. H. Schukken. 2007. Effect of repeated episodes of generic clinical mastitis on milk yield in dairy cows. J. Dairy Sci. 90:4643-4653.

Bar, D., Y. T. Gröhn, G. Bennett, R. N. González, J. A. Hertl, H. Schulte, L. W. Tauer, F. L. Welcome, and Y. H. Schukken. 2008a. Effects of repeated episodes of generic clinical mastitis on mortality and culling in dairy cows. J. Dairy Sci. 91:2196-2204.

Bar, D., L. W. Tauer, G. Bennett, R. N. González, J. A. Hertl, Y. H. Schukken, H. F. Schulte, F. L. Welcome, and Y. T. Gröhn. 2008b. The cost of generic clinical mastitis in dairy cows as estimated by using dynamic programming. J. Dairy Sci. 91:2205-2214.

Barkema, H. W., Y. H. Schukken, T. J. Lam, M. L. Beiboer, H. Wilmink, G. Benedictus, and A. Brand. 1998. Incidence of clinical mas- 
titis in dairy herds grouped in three categories by bulk milk somatic cell counts. J. Dairy Sci. 81:411-419.

Bradley, A. J., and M. Green. 2001. Aetiology of clinical mastitis in six Somerset dairy herds. Vet. Rec. 148:683-686.

Compton, C. W. R., C. Heuer, K. Parker, and S. McDougall. 2007. Epidemiology of mastitis in pasture-grazed peripartum dairy heifers and its effects on productivity. J. Dairy Sci. 90:4157-4170.

Dechow, C. D., and R. C. Goodling. 2008. Mortality, culling by sixty days in milk, and production profiles in high- and low-survival Pennsylvania herds. J. Dairy Sci. 91:4630-4639.

Fetrow, J., K. V. Nordlund, and H. D. Norman. 2006. Invited review: Culling: Nomenclature, definitions, and recommendations. J. Dairy Sci. 89:1896-1905.

Gröhn, Y. T., S. W. Eicker, V. Ducrocq, and J. A. Hertl. 1998. Effect of diseases on the culling of Holstein dairy cows in New York State. J. Dairy Sci. 81:966-978.

Gröhn, Y. T., R. N. González, D. J. Wilson, J. A. Hertl, G. Bennett, H. Schulte, and Y. H. Schukken. 2005. Effect of pathogen-specific clinical mastitis on herd life in two New York State dairy herds. Prev. Vet. Med. 71:105-125.

Gröhn, Y. T., D. J. Wilson, R. N. González, J. A. Hertl, H. Schulte, G. Bennett, and Y. H. Schukken. 2004. Effect of pathogen-specific clinical mastitis on milk yield in dairy cows. J. Dairy Sci. $87: 3358-3374$.

Hedeker, D., O. Siddiqui, and F. B. Hu. 2000. Random-effects regression analysis of correlated grouped-time survival data. Stat. Methods Med. Res. 9:161-179.

Hertl, J. A., Y. T. Gröhn, J. D. G. Leach, D. Bar, G. J. Bennett, R. N. González, B. J. Rauch, F. L. Welcome, L. W. Tauer, and Y. H. Schukken. 2010. Effects of clinical mastitis caused by grampositive and gram-negative bacteria and other organisms on the probability of conception in New York State Holstein dairy cows. J. Dairy Sci. 93:1551-1560.

Huszenicza, G., S. Jánosi, M. Kulcsár, P. Kóródi, J. Reiczigel, L. Kátai, A. R. Peters, and F. de Rensis. 2005. Effects of clinical mastitis on ovarian function in post-partum dairy cows. Reprod. Domest. Anim. 40:199-204.

Kleinbaum, D. G., L. L. Kupper, and H. Morgenstern. 1982. Epidemiological Research, Principles and Quantitative Methods. Van Nostrand Reinhold, New York, NY.

Koskinen, M. T., G. J. Wellenberg, O. C. Sampimon, J. Holopainen A. Rothkamp, L. Salmikivi, W. A. van Haeringen, T. J. Lam, and S. Pyörälä. 2010. Field comparison of real-time polymerase chain reaction and bacterial culture for identification of bovine mastitis bacteria. J. Dairy Sci. 93:5707-5715.

Milne, M. H., A. M. Biggs, J. L. Fitzpatrick, G. T. Innocent, and D. C. Barrett. 2003. Use of clinical information to predict the characteristics of bacteria isolated from clinical cases of bovine mastitis. Vet. Rec. 152:615-617.

Morin, D. E., and P. D. Constable. 1998. Characteristics of dairy cows during episodes of bacteriologically negative clinical mastitis or mastitis caused by Corynebacterium spp. J. Am. Vet. Med. Assoc. 213:855-861.

Neerhof, H. J., P. Madsen, V. P. Ducrocq, A. R. Vollema, J. Jensen, and I. R. Korsgaard. 2000. Relationship between mastitis and functional longevity in Danish Black and White dairy cattle estimated using survival analysis. J. Dairy Sci. 83:1064-1071.
Neeser, N. L., W. D. Hueston, S. M. Godden, and R. F. Bey. 2006. Evaluation of the use of an on-farm system for bacteriologic culture of milk from cows with low-grade mastitis. J. Am. Vet. Med. Assoc. 228:254-260.

Perrin, L., R. W. Bostelmann, and I. M. Sheldon. 2007. Reduced conception rates associated with bovine mastitis during a "window of opportunity'. Vet. Rec. 161:61-62.

Pyörälä, S., L. Kaartinen, H. Käck, and V. Rainio. 1994. Efficacy of two therapy regimens for treatment of experimentally induced Escherichia coli mastitis in cows. J. Dairy Sci. 77:453-461.

Roberson, J. R. 2003. Establishing treatment protocols for clinical mastitis. Vet. Clin. North Am. Food Anim. Pract. 19:223-234.

Sampimon, O., H. W. Barkema, I. Berends, J. Sol, and T. Lam. 2009. Prevalence of intramammary infection in Dutch dairy herds. J. Dairy Res. 76:129-136.

Santos, J. E. P., R. L. A. Cerri, M. A. Ballou, G. E. Higginbotham, and J. H. Kirk. 2004. Effect of timing of first clinical mastitis occurrence on lactational and reproductive performance of Holstein dairy cows. Anim. Reprod. Sci. 80:31-45.

SAS Institute. 2006. SAS OnlineDoc 9.1.3. SAS Institute Inc., Cary, $\mathrm{NC}$.

Schukken, Y. H., D. Bar, J. A. Hertl, and Y. T. Gröhn. 2010. Correlated time to event data: Modeling repeated clinical mastitis data from dairy cattle in New York State. Prev. Vet. Med. 97:150-156.

Schukken, Y. H., J. A. Hertl, D. Bar, G. Bennett, R. N. González, B. Rauch, C. Santisteban, H. F. Schulte, L. W. Tauer, F. L. Welcome, and Y. T. Gröhn. 2009. Effects of repeated gram-positive and gram-negative clinical mastitis episodes on milk yield loss in Holstein dairy cows. J. Dairy Sci. 92:3091-3105.

Seegers, H., C. Fourichon, and F. Beaudeau. 2003. Production effects related to mastitis and mastitis economics in dairy cattle herds. Vet. Res. 34:475-491.

USDA-Economic Research Service. 2010. Monthly milk costs of production. Accessed Jan.17, 2011. http://www.ers.usda.gov/Data/ CostsAndReturns/TestPick.htm\#milkproduction.

USDA-National Agricultural Statistics Service. 2009. Table 80. Prices received by farmers: Selected livestock commodities, monthly and marketing year average, New York, 1999 to date. Accessed Jan. 18 , 2011. http://www.nass.usda.gov/Statistics_by_State/New_York/ Publications/Annual_Statistica l_Bulletin/2009/Bulletin2009.pdf

Waage, S., P. Jonsson, and A. Franklin. 1994. Evaluation of a cow-side test for detection of gram-negative bacteria in milk from cows with mastitis. Acta Vet. Scand. 35:207-212.

Waage, S., H. R. Skei, J. Rise, T. Rogdo, S. Sviland, and S. A. Ødegaard. 2000. Outcome of clinical mastitis in dairy heifers assessed by reexamination of cases one month after treatment. J. Dairy Sci. $83: 70-76$

Wenz, J. R., G. M. Barrington, F. B. Garry, K. D. McSweeney, R. P. Dinsmore, G. Goodell, and R. J. Callan. 2001. Bacteremia associated with naturally occurring acute coliform mastitis in dairy cows. J. Am. Vet. Med. Assoc. 219:976-981.

Whist, A. C., O. Osterås, and L. Sølverød. 2009. Association between isolation of Staphylococcus aureus one week after calving and milk vield, somatic cell count, clinical mastitis, and culling through the remaining lactation. J. Dairy Res. 76:24-35. 